and limber pine (Pinus flexilis) occur at various piaces and Engelmann spruce (Picea engelmanni) comes in at the upper limit of the zone.

4. Sub-alpine Zone.-Altitude 10,000 to 11,500 feet. This zone is characterized by forests of Engelmann spruce with limber pine and balsam fir (Abies lasiocarpa) as secondary species. Huckleberries are abundant as shade plants on the forest floor. A considerable amount of grassland or steppe occurs in the form of mountain meadows in the upper part of the zone. "Wind timber" runs up in tongues to various altitudes and there are small patches of this scrub formation isolated from the main mass below. Numerous ponds and bogs occur along stream-courses.

5. Alpine Zone.-Altitude 11,500 to 14,000 feet and higher. This is a rock-desert and steppe zone. Mat-forming plants and deeprooted perennials are common. Large areas, consisting of rock heaps and boulder fields, are practically destitute of all vegetation except lichens. Sedges and grasses are numerous in species but seldom form a dense sod, being mixed with various flowering herbs. Dwarf willows occur, often forming a dense scrub over large areas, but there are no other woody plants.

University of Colorado, BOULDER, Colo.

\section{THE INTERCOLLEGIATE GEOLOGICAL EXCURSION}

The seventh annual New England Geological Excursion was held at Providence, Rhode Island, on Saturday, October 26, under the leadership of Professor Chas W. Brown, of Brown University.

Friday evening a short conference was held at which the route planned was explained. The purpose of the trip was to study the undisturbed Carboniferous shales and sandstones with their fossil contents that occur east of the city of Providence and the graphite mine and sheaved basal conglomerate to the west of the city. Professors B. K. Emerson, J. B. Woodworth and Chas. W. Brown explained the structural and metamorphic features of the sections visited. The attendance of pro- fessors and graduate students was rather larger than in previous years.

In addition to the advanced students and teachers from the high schools and normal schools the following institutions were represented in the party of seventy: Amherst, Professor B. K. Emerson; Brown, Professors Brown and Ward; Colby, Professor H. E. Simpson; Holyoke, Professor Mignon Talbot; Harvard, Professors Johnson, Wolff, Woodworth and Dr. Mansfield; Massachusetts Institute of Technology, Professors Jaggar and Daly and Dr. Shimer; Smith, Miss Aida A. Heine; Williams, Professor H. F. Cleland; Yale, Professors Barrell, Gregory and Schuchert; Worcester, Mr. J. H. Perry; Worcester Normal School, R. M. Brown.

The next meeting will probably be held in the northern Berkshires in the vicinity of Williams College.

\section{Herdman F. Cleland, Secretary}

\section{THE LAMARCK MEMORIAL}

Mr. Alexander Agassiz, Professor Henry Fairfield Osborn and Professor Bashford Dean, members of the International Committee from the United States, have issued a statement to the effect that the International Committee entrusted to secure funds for the monument to Lamarck has up to the present time received subscriptions amounting to about 25,000 francs. And the prompt response to the notices sent out by the committee has been, in many cases, very gratifying-Montevideo, for example, sending in the names of seventy-seven subscribers. There remains to be raised, however, the sum of 5,000 francs. And it is with the hope of securing the final amount that the American members of the committee are sending out this second notice. It is earnestly wished that this sum be contributed from the United States, in view of the influence which Lamarck has had upon the evolutionary conceptions of many and prominent American naturalists.

Subscriptions should be sent, as soon as possible, to Bashford Dean (Columbia University, New York), who will duly acknowledge and transmit them to the headquarters of the committee in Paris. 